Nowoczesne Systemy Zarządzania

Zeszyt 16 (2021), nr 1 (styczeń-marzec)

ISSN 1896-9380, s. 87-96

DOI: $10.37055 / \mathrm{nsz} / 134810$

Modern Management Systems

Volume 16 (2021), No. 1 (January-March)

ISSN 1896-9380, pp. 87-96

DOI: $10.37055 / \mathrm{nsz} / 134810$
Instytut Organizacji i Zarządzania Wydział Bezpieczeństwa, Logistyki i Zarządzania

Wojskowa Akademia Techniczna

w Warszawie

Institute of Organization and Management Faculty of Security, Logistics and Management Military University of Technology

in Warsaw

\title{
A multidimensional comparative analysis of the decline in the number of passengers transported by air in Germany in 2020
}

\section{Wielowymiarowa analiza porównawcza spadków liczby pasażerów przewiezionych transportem lotniczym w Niemczech w 2020 roku}

\author{
Bartosz Kozicki \\ Military University of Technology, \\ Faculty of Security, Logistics and Management \\ e-mail: bartosz.kozicki@wat.edu.pl; ORCID: 0000-0001-6089-952x
}

\begin{abstract}
The study presents a multidimensional comparative analysis of the decline in the number of passengers transported by air in Germany in 2020. The number of passengers in 2019 and 2020 as well as the forecast of the number of passengers transported in Germany for 2020 with actually transported passengers this year were compared. The Holt-Winters' exponential smoothing method was used for forecasting. The obtained research results are important in terms of planning and ensuring the economic security of the air transport sector in Germany.

Keywords: air transport, COVID-19, multidimensional comparative analysis, forecasting, economic security

Abstrakt. W opracowaniu przeprowadzono wielowymiarową analizę porównawczą spadku liczby pasażerów przewiezionych transportem lotniczym w Niemczech w 2020 roku. Zestawiono liczbę pasażerów w 2019 i 2020 roku oraz wykonaną prognozę liczby pasażerów przewiezionych w Niemczech na 2020 rok z faktycznie przewiezionymi pasażerami w tym roku. Do prognozowania wykorzystano metodę wygładzania wykładniczego Holta-Wintersa. Uzyskane wyniki badań są ważne w aspekcie planowania i zapewnienia bezpieczeństwa ekonomicznego sektora transportu lotniczego w Niemczeczech.

Słowa kluczowe: transport lotniczy, COVID-19, wielowymiarowa analiza porównawcza, prognozowanie, bezpieczeństwo ekonomiczne
\end{abstract}




\section{Introduction}

Until 2019, air transport was one of the fastest growing branches of broadly understood transport in the world. Its slowdown was caused by the COVID-19 pandemic which led to global decline in the number of passengers transported in 2020.

The aim of the article is an attempt to conduct a multidimensional comparative analysis of the decline in the number of passengers transported by air in Germany in 2020 caused by the COVID-19 pandemic. The subject of the research is the passengers transported by air in Germany.

The article uses research methods in the form of: literature analysis, which concerned air passenger transport, as well as a multidimensional comparative analysis of forecasting and economic security. In this study, for research and illustrative purposes, the data obtained from Eurostat was grouped and specified in terms of their further analysis, evaluation and regularity detection.

The study consists of an introduction, two substantive points, a summary and conclusions.

\section{Analysis of the literature on the subject of research}

The analysis of the literature shows that transport is the provision of services consisting in the movement of loads or additional services directly related to it (Neider, 2008, p. 5). It is associated with the production process, the aim of which is to cover a distance (Jacyna, Lewczuk, 2016, p. 88). It is an element of the socioeconomic infrastructure, identified with a part of the socio-economic system (Ciesielski, Gołembska, 1999, p. 105). To sum up, transport means moving cargo and people from A to B using appropriate means of transport. An important aspect related to transport, raised by researchers, is the so-called flow efficiency, i.e. product delivery at the right time, place and in accordance with the dispatcher's instructions (Skowronek, Sarjusz-Wolski, 2008, p. 85).

One of the types of transport is the air transport, which can only take place between properly prepared places, such as landing sites, airports or aerial ports (Wojewódzka-Król, Załoga, 2016, p. 235). Air transport is considered to be the fastest and, at the same time, unrivaled in relation to other means of transport (Czech, Kwasiborowska, 2016, p. 12). It allows people to move quickly and safely to any place in the world and thus make purchase and sale transactions.

Air transport is one of the factors influencing the economic growth of countries. In Europe, the leader in terms of the number of passengers transported by passenger air transport is Germany. In the period from 2015 to 2019, each year in Germany an increase in the number of passengers was visible, as well as a clear seasonality 
on a monthly basis. In March 2020, the COVID-19 pandemic was announced (https://pulsmedycyny.pl/who-grozba-pandemii-koronawirusa-jest-realna-984550; Satomi et al., 2020). The first cases of an infectious disease were recorded in China in December 2019 (Tia et al., 2020; Zhu, Zhang, Wang et al., 2020).

The infectious disease COVID-19 resulted in the introduction of numerous restrictions around the world, including: the use of face masks in everyday life, disinfectants and various types of mobility restrictions and the prohibition of group meetings (Yan et al., 2020; Pike, Saini, 2020).

In 2020, a decrease in the number of passengers transported by air was observed in all countries of the world. The article attempts to estimate the decrease in the number of people transported by passenger air transport in Germany.

To achieve this goal, a multi-dimensional comparative analysis and forecasting were used. According to Euniewska, the multivariate comparative analysis is a group of statistical methods that simultaneously analyze at least two variables describing each object (Łuniewska, Tarczyński, 2006, p. 9). The literature also indicates that the multivariate comparative analysis is a set of methods for detecting regularities in multidimensional communities of research objects (Gorzelak, 1981, pp. 16-19). The study uses specifying and grouping of data obtained from the Eurostat website.

Forecasting is a rational, scientific prediction of future events (Dittmann, 2016, p. 20). The scheme and procedures are described in many references but it should be emphasized that they diverge (Makridakis, Wheelwright, Hyndman, 1998; Kozicki, 2020). The purpose of forecasting is to reduce the risk of making a mistake.

In the study, the Holt-Winters' method was used for the forecasting of the number of passengers transported by air transport in Germany for 2020, the methodology of which has been widely described in various publications (Kot, Jakubowski, Sokołowski, 2011; Mitkow, Kozicki, Mizura, 2020).

The study presents two lists of data: the number of passengers transported by air transport in Germany in 2020 was compared to that of 2019, as well as the forecast of the number of passengers for 2020 made using the Holt-Winters' method with the actual number of passengers - in terms of ensuring economic security.

According to Nurzyńska, economic security is the certainty of survival and development of the economic system of the state and international economic organizations with their instruments (Nurzyńska, 2016, p. 23). Estimating the decline in the number of passengers transported by air transport in Germany, as the leader of the European Union, in 2020 aims to improve planning in the air transport sector in terms of implementing appropriate solutions that will lead to an increase in the dynamics of the number of people transported by air transport and a return to the state observed before the pandemic COVID-19. 


\section{Multidimensional comparative analysis of the number of passengers transported by air in Germany}

The research began with drawing a line chart of people transported by passenger air transport in Germany on a monthly basis between 2015-2020.

The observations of the data presented in Figure 1 prove that from 2015 to 2019 in Germany there was a growing trend and a monthly seasonality in the number of passengers transported by air. The arithmetic mean of the number of these passengers between 2015-2019 was 17,603,325 and the median was 18,038,469. The standard deviation from the arithmetic mean was $3,401,553$ passengers in the analyzed period. Since March 2020, there has been a visible decrease in the number of passengers transported by air in Germany caused by the COVID-19 pandemic. The arithmetic mean of the number of passengers transported in Germany on a monthly basis in 2020 was $4,816,332$, while the median was lower and oscillated around 3,981,570 passengers. The standard deviation from the arithmetic mean amounted to $4,677,619$ passengers.

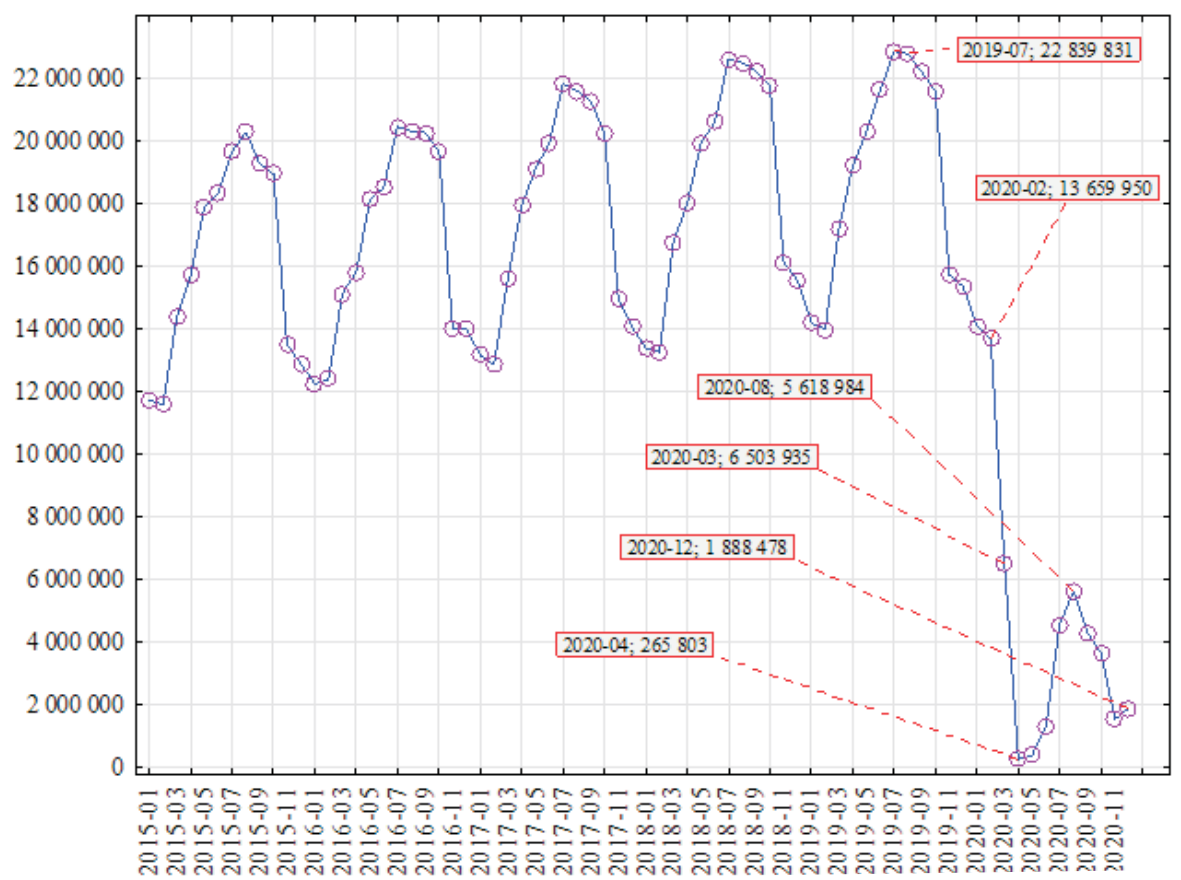

Fig. 1. Linear chart of the number of people transported by passenger air transport in Germany on a monthly basis between 2015-2020

Source: Own study based on data obtained from the website: https://ec.europa.eu/, as of March 9, 2021 
Figure 1 shows the visible decrease in the number of passengers transported by air in Germany in 2020. It should be emphasized that in 2019 - 226764086 people were transported by air transport and in 2020 their number decreased to 57795978 .

For illustrative purposes, a comparative analysis in the form of a bar chart of the number of passengers transported by air in Germany on a monthly basis between 2019 and 2020 was carried out in Figure 2. The data presented in Figure 2 shows that from March, the difference between the number of passengers transported by air in Germany between 2019 and 2020 begins to increase. The biggest difference (in absolute values) was observed in June (20 271 471). Then the respective months were ranked in the following order (absolute values): May (19,855,468), April $(18,925,017)$, July $(18,283,229)$, October $(17,910,507)$, September $(17,875,430)$, August (17 137 849), November (14 155 320), December (13 451 979), March (10 688 638), February (305 813) and January (107 387).

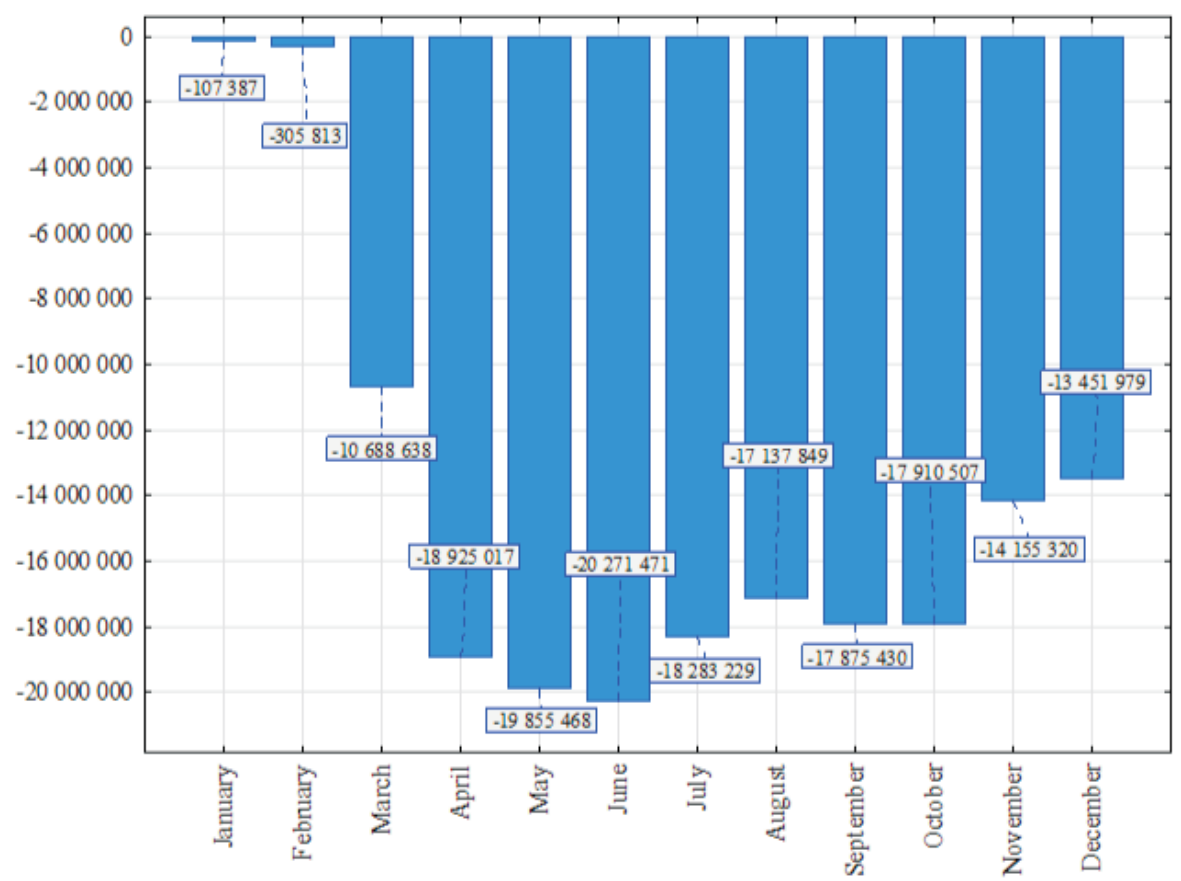

Fig. 2. Bar chart of the difference in the number of people transported by passenger air transport in Germany on a monthly basis between 2019 and 2020

Source: Own study based on data obtained from the website: https://ec.europa.eu/, as of March 9, 2021

The arithmetic mean of the number of passengers transported by air on a monthly basis in Germany in 2019 amounted to 18897007 people. In 2020, the arithmetic mean dropped to 4,816,332 passengers. The median of the number of transported 
passengers on a monthly basis in 2019 in Germany amounted to 19722002 while in 2020 it decreased to the level of 3981570 passengers. The standard deviation from the arithmetic mean in 2019 amounted to 3,436,551 passengers and in 2020 increased to 4,677,619 passengers.

According to the author of the study, the mere comparison (examination of the difference) between 2019 and 2020 in terms of the number of passengers transported by air in Germany is insufficient because if the COVID-19 pandemic did not occur in 2020, the growing trend in the number of passengers transported by air would be maintained and seasonality on a monthly basis visible out of previous years (from 2015 to 2019). Thus, the difference between the forecast of the number of passengers transported by air in Germany and the actual number of passengers transported should be higher.

For research purposes, Figure 3 presents the results of forecasting the number of passengers transported by air in Germany for 2020 on a monthly basis, made using the Holt-Winters' exponential smoothing method - together with actually transported passengers between 2015 and 2020 on a monthly basis.

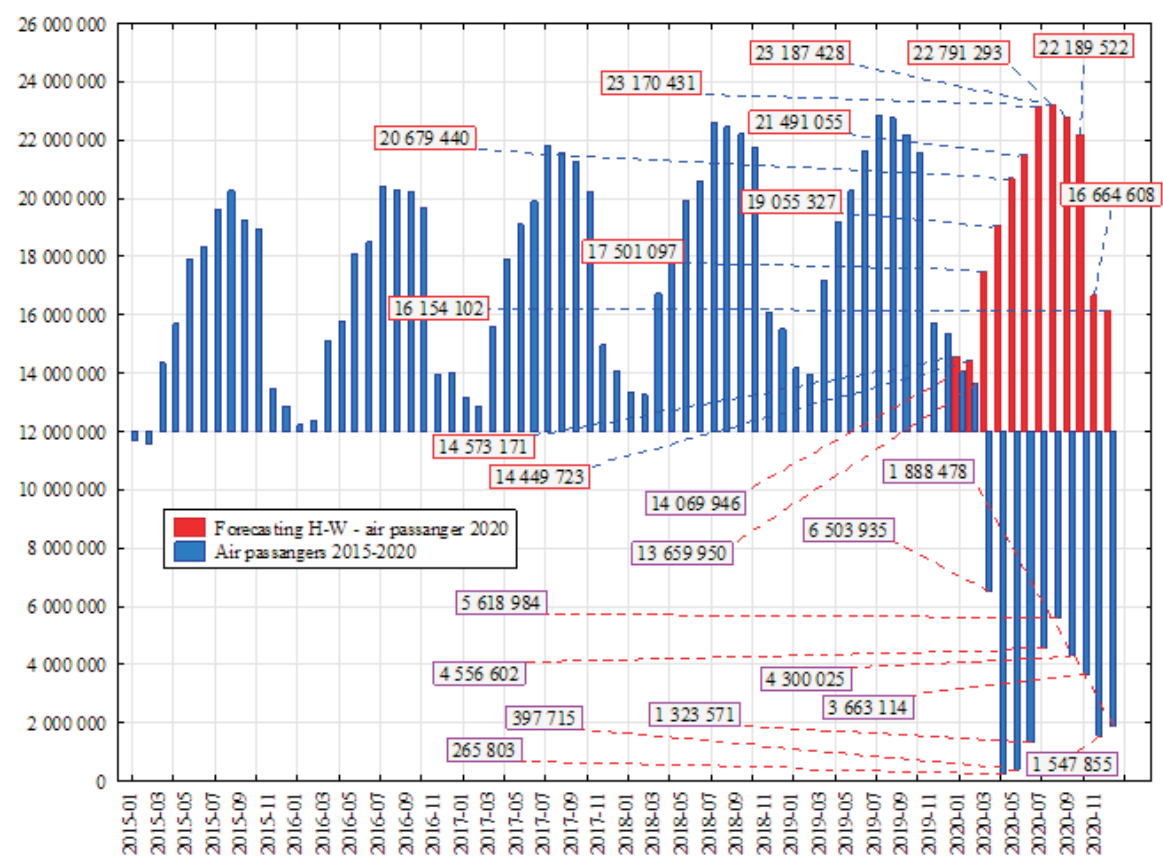

Fig. 3. Comparative analysis bar chart: the number of people transported by passenger air transport in Germany on a monthly basis and the $\mathrm{H}-\mathrm{W}$ forecast of the number of passengers transported by air on a monthly basis for 2020

Source: Own study based on data obtained from the website: https://ec.europa.eu/, as of March 9, 2021 
The monthly forecasts of the number of passengers for 2020 presented in Figure 3 show that in 2020 in total approximately 231,907,197 passengers should be transported while, in fact, $57,795,978$ passengers were transported. The arithmetic mean of the forecast for 2020 outlined in Figure 3 is 19,325,600 passengers while the actual average was $4,816,332$ passengers. The median of the forecast made by the Holt-Winters' method of the number of passengers transported for 2020 in Germany on a monthly basis was $19,867,384$ people. It should be emphasized that the real median in 2020 is $3,981,570$ passengers. The standard deviation from the arithmetic mean of the obtained forecast of the number of passengers transported by air for 2020 is 3,348,349 passengers and, due to the impact of COVID-19 in 2020 in Germany, it actually increased to the level of 4,677,619 passengers.

For illustrative purposes, a comparative analysis in the form of a bar chart of the number of passengers transported by air in Germany on a monthly basis between 2019 and 2020 was carried out in Figure 2.

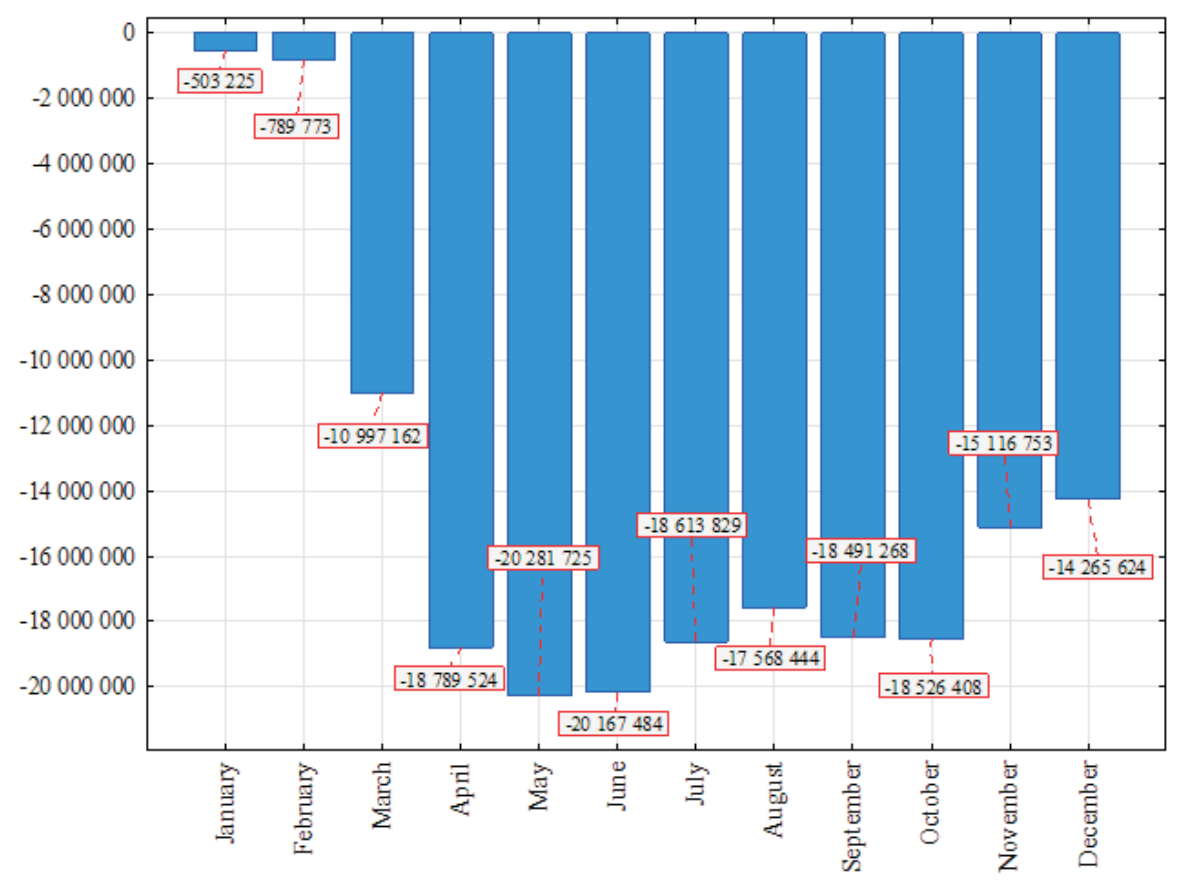

Fig. 4. Bar chart of the difference in the actual number of passengers transported by passenger air in Germany on a monthly basis between 2020 and the H-W forecast for 2020

Source: Own study based on data obtained from the website: https://ec.europa.eu/, as of March 9, 2021 
The ranking of differences between actually transported people and the forecast of the number of passengers transported by air in Germany for 2020 (Fig. 4) is as follows (from the largest to the smallest difference in absolute value): May (20 281 725), June (20 167 484), April (18,789,524), July (18,613,829), October (18,526,408), September $(18,491,268)$, August $(17,568,444)$, November $(15,116,753)$, March $(10,997,162)$, February $(789,773)$ and January $(503,225)$.

The conducted analyzes show an increase in the difference between the data outlined in Figure 2 and the forecast of the number of passengers transported by air, carried out using the Holt-Winters' exponential smoothing method for 2020 and actually transported passengers in 2020 in Germany (Figure 4). The results of the comparative analysis of the two differences are outlined on a bar chart (Fig. 5).

When comparing the number of passengers actually transported in Germany by air in 2020, a decrease was recorded compared to 2019 by 168968108 passengers (difference I). The comparative analysis (Fig. 5) shows that in 2020 the number of passengers transported by air in Germany, compared to the forecasts obtained after applying the Holt-Winters' exponential smoothing method for 2020, decreased by 174,111 2019 people (difference II).

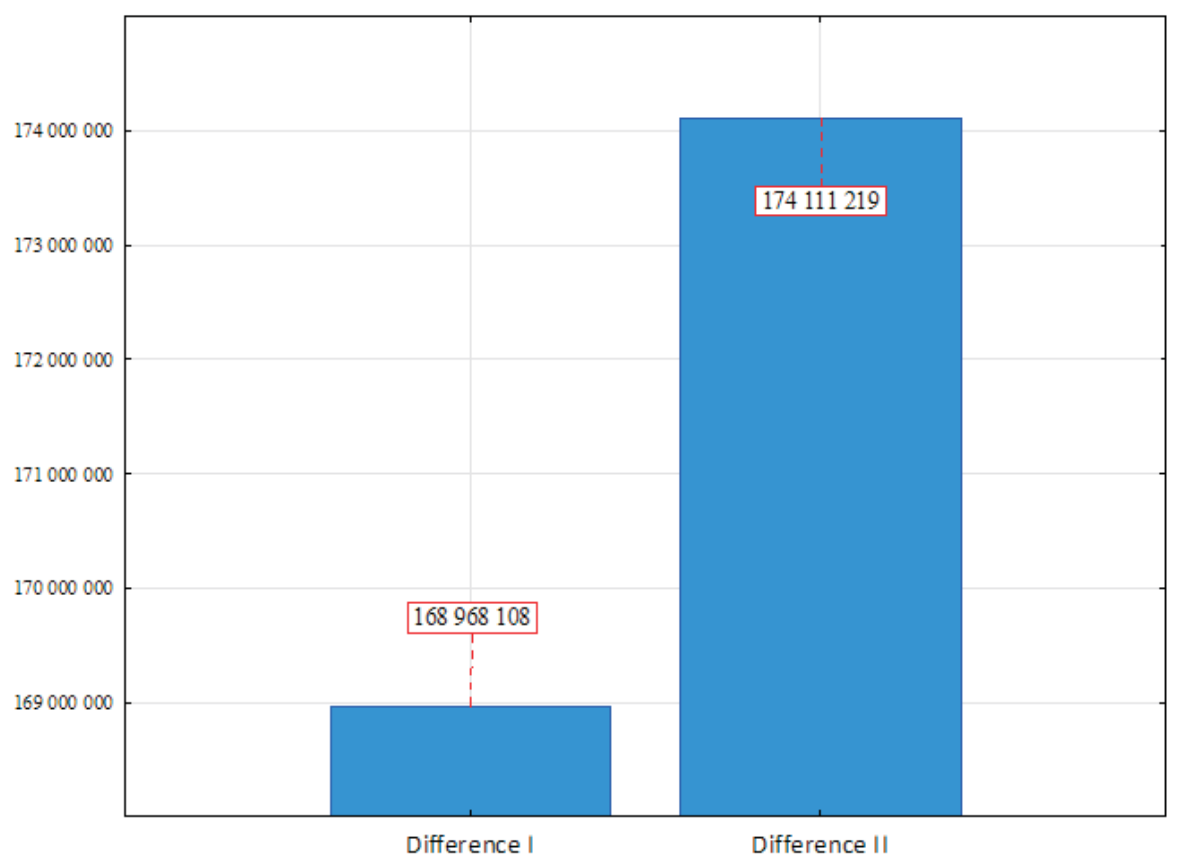

Fig. 5. Bar charts of the comparative analysis of the difference in the number of passengers transported by air in Germany between: 2019 and 2020 (difference I) and 2020 and Holt-Winters' forecast for this year (difference II)

Source: Own study based on data obtained from the website: https://ec.europa.eu/, as of March 9, 2021 
According to the author of the study, the second difference (174 111219) more accurately reflects the losses related to the decrease in the number of passengers transported by air in Germany caused by the COVID-19 pandemic.

\section{Summary and conclusions}

Passenger air transport as a result of the COVID-19 pandemic recorded large financial losses due to the decrease in the number of passengers transported in 2020. The study analyzed and evaluated the number of passengers transported by air in dynamic terms in Germany, being the leader of the European Union in this aspect.

The conducted research shows that the largest difference in passenger transport by air in Germany between 2019 and 2020 (in absolute values) was observed in the following months: June (20 271 471), May (19 855 468), April (18 925 017), July $(18,283,229)$, October $(17,910,507)$, September $(17,875,430)$, August $(17,137,849)$, November $(14,155,320)$, December $(13,451,979)$, March $(10,688,638)$, February $(305,813)$ and January $(107,387)$. The arithmetic mean of the number of passengers by air transport on a monthly basis in Germany in 2019 amounted to 18897007 people. In 2020, the arithmetic mean dropped to 4,816,332 passengers.

In the study, a second comparative analysis was carried out by comparing the data on the number of passengers transported by air in 2020 with the forecast of the number of passengers in Germany for 2020 using the Holt-Winters' method. The ranking of differences between the actually transported passengers and the forecast of the number of passengers transported by air in Germany for 2020 (Fig. 4 ) is as follows (from the greatest to the smallest difference in absolute value): May (20 281 725), June (20 167 484), April (18,789,524), July (18,613,829), October $(18,526,408)$, September $(18,491,268)$, August $(17,568,444)$, November $(15,116,753)$, March $(10,997,162)$, February $(789,773)$ and January $(503,225)$.

The research shows that the difference of 174111219 passengers between the forecast for 2020 and the actual air transport of passengers accurately reflects the losses related to the decrease in the number of passengers transported by air in Germany caused by the COVID-19 pandemic.

The increase in the number of passengers transported in Germany and in the world in the following years requires the development and implementation of international agreements which will define standards guaranteeing transport safety and its quality. One of the priorities will certainly be vaccinating the majority of the population with the vaccine aimed at overcoming the infectious disease COVID-19. This, in turn, will be a prerequisite for implementing activities aimed at increasing the dynamics of transport and returning to the state observed before the COVID-19 pandemic. At this stage, it is important to thoroughly analyze the losses associated with the slowdown in passenger air transport in terms of, for example, allocating financial outlays for its reconstruction and ensuring economic security in this matter. 


\section{REFERENCES}

[1] Czech, P., Kwasiborowska, A., 2016, Bezpieczeństwo transportu lotniczego. Wybrane aspekty, Pułtusk: Oficyna Wydawnicza ASPRA-JR.

[2] Dittmann, P., 2016, Prognozowanie w przedsiębiorstwie. Metody i ich zastosowanie, Kraków: Wolters Kluwer.

[3] GoŁembska, E. (red.), 1999, Kompendium wiedzy o logistyce, Warszawa-Poznań: Wydawnictwo Naukowe PWN.

[4] Gorzelak, G., 1981, Statystyczna analiza porównawcza - teoria a praktyka, Wiadomości Statystyczne, 8.

[5] https://pulsmedycyny.pl/who-grozba-pandemii-koronawirusa-jest-realna-984550 (10.03.2021).

[6] JaCyna, M., LewCZuK, K., 2016, Projektowanie systemów logistycznych, Warszawa: Wydawnictwo Naukowe PWN.

[7] Кот, S.M., Jакuвоwsкi, J., Sокоєоwsкi, A., 2011, Statystyka, Warszawa: Difin.

[8] Kozicki, B., 2020, A New Method for Planning Needs in Terms of Security, International Business Information Management.

[9] Łuniewska, M., TARCZyŃski, W., 2006, Metody wielowymiarowej analizy porównawczej na rynku kapitałowym, Warszawa: Wydawnictwo Naukowe PWN.

[10] Makridakis, S.G., Wheelwright, S.C., Hyndman, R.J., 1998, Forecasting methods and applications, New York: John Wiley and Sons.

[11] Mitкow, Sz., Kozicki, B., Mizura, G., 2020, Metodyka wielomodelowego prognozowania wydatków w aspekcie bezpieczeństwa ekonomicznego, Systemy Logistyczne Wojsk, 2.

[12] Neider, J., 2008, Transport międzynarodowy, Warszawa: Polskie Wydawnictwo Ekonomiczne.

[13] NuRzyŃska, A., 2016, Bezpieczeństwo usług w międzynarodowym transporcie lotniczym przewozów pasażerskich, Katowice: Wydawnictwo Naukowe SOPHIA.

[14] Pike, T.W., SAInI, V. 2020, An international comparison of the second derivative of COVID-19 deaths after implementation of social distancing measures, https://doi.org/10.1101/2020.03.25.20041475 (3.04.2020).

[15] SAtomi, E. ET AL., 2020, Alocação justa de recuros de saúde escassos diante da pandemia de COVID-19, Considerações éticas, 18(2), 1-5.

[16] Skowronek, Cz., Sarjusz-Wolski, Z., 2008, Logistyka w przedsiębiorstwie, Warszawa: Polskie Wydawnictwo Ekonomiczne.

[17] Tia, H. ET AL., 2020, An investigation of transmission control measures during the first 50 days of the COVID-19 epidemic in China, Science, 368, 638-642.

[18] Wojewódzka-KróL, K., Za£oga, E., 2016, Transport. Nowe wyzwania, Warszawa: Wydawnictwo Naukowe PWN.

[19] YAN, Y., ET AL., 2020, The First 75 Days of Novel Coronavirus (SARS-CoV-2) Outbreak: Recent Advances, Prevention, and Treatment, Int J Environ Res Public Health, 17(7).

[20] Zhu, N., Zhang, D., Wang, W., Li, X., YAng, B., Song, J., ET AL., 2020, A Novel Coronavirus from Patients with Pneumonia in China, New England Journal of Medicine. 